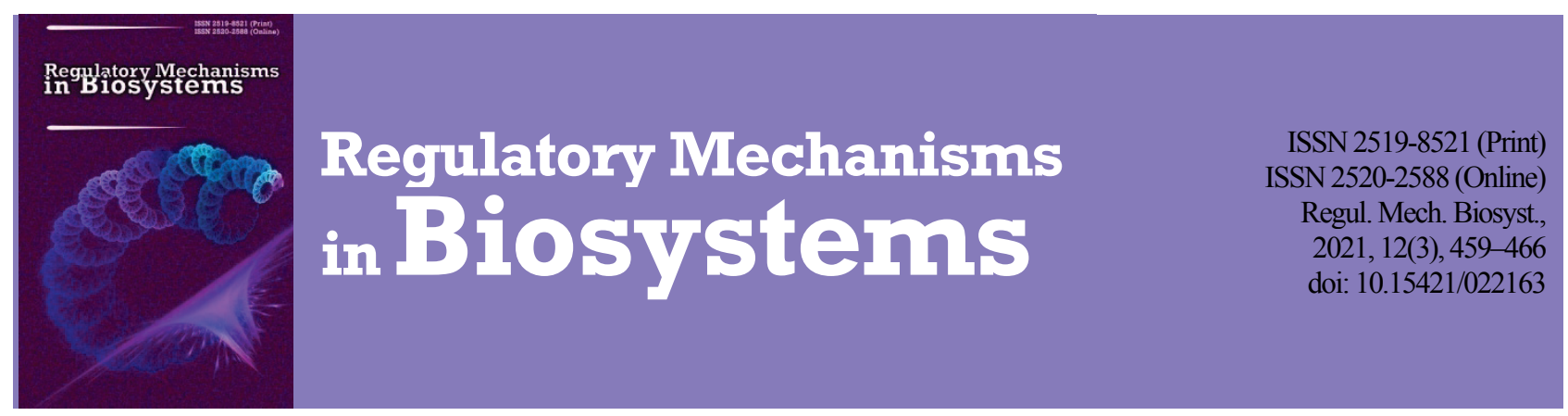

\title{
Influence of crude oil pollution on the content and electrophoretic spectrum of proteins in Carex hirta plants at the initial stages of vegetative development
}

\author{
L. V. Bunio, O. M. Tsvilynyuk \\ Ivan Franko National University, Lviv, Ukraine
}

Article info

Received 20.06.2021

Received in revised form 17.07.2021

Accepted 18.07.2021

Ivan Franko National

University of Lviv,

Hrushevsky st., 4,

Lviv, 79005, Ukraine.

Tel.: +38-067-802-07-81.

E-mail:

bunio.lyubov@gmail.com
Bunio, L. V., \& Tsvilynyuk, O. M. (2021). Influence of crude oil pollution on the content and electrophoretic spectrum of proteins in
Carex hirta plants at the initial stages of vegetative development. Regulatory Mechanisms in Biosystems, 12(3), 459-466.
doi:10.15421/022163
The role of proteins in the general adaptive response of Carex hirta plants to soil pollution by crude oil has been studied. It was established that a possible element of the process of adaptation of $C$. hirta plants to combined stress - conditions of soil polluted by crude oil may be the synthesis of stress proteins - high molecular weight of more than $60 \mathrm{kD}$ and low molecular weight, not exceeding $22-45 \mathrm{kD}$. The synthesis of all 5 HSP families was detected in the leaves and rhizomes, and only sHSP (starting from Mr $32 \mathrm{kD}$ ), Hsp 60 and Hsp 100 proteins were synthesized in the roots under the influence of crude oil pollution. The development of $C$. hirta adaptation syndrome under the influence of crude oil pollution of the soil was promoted by enhanced synthesis of proteins with $\mathrm{Mr} 85,77,64,60$ and $27 \mathrm{kD}$ in the leaves,

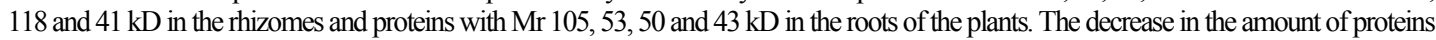
with $\mathrm{Mr} 91,45,28 \mathrm{kD}$ in the leaves, proteins with $\mathrm{Mr} 85,76$ and $23 \mathrm{kD}$ in rhizomes and proteins with $\mathrm{Mr} 64$ and 39 in the roots of C. hirta plants under conditions of crude oil polluted soil could be a consequence of inhibition of synthesis or degradation of protein molecules providing the required level of low molecular weight protective compounds in cells. The root system and rhizomes of $C$. hirta plants undergo a greater crude oil load, which leads to increased protein synthesis in these organs and decreased in the leaves, correspondingly. However, a decrease in protein content in the leaves may indicate their outflow in the roots and rhizomes. Crude oil contaminated soil as a polycomponent stressor accelerated the aging of leaves of $C$. hirta plants, which could be caused by increased synthesis of ABA. ABA in its turn induced the synthesis of leaf-specific protein with $\mathrm{Mr} 27 \mathrm{kD}$. These proteins bind significant amounts of water with their hydrate shells maintaining the high water holding capacity of the cytoplasm under drought conditions. ABA inhibits the mRNA synthesis and their corresponding proteins, which are characteristic under normal conditions, and induces the expression of genes and, consequently, the synthesis of specific proteins including $27 \mathrm{kD}$ protein. By stimulating the expression of individual genes and the synthesis of new polypeptides, ABA promotes the formation of protective reactions and increases the resistance of plants to crude oil pollution.

Keywords: adaptation syndrome; heat shock protein; abscisic acis (ABA); crude oil; soil.

\section{Introduction}

Studies of a plant's response to stress are usually monofactorial. The effect of hyperthermia or drought on the plant organism or another influencing factor is studied separately. Each abiotic stress causes a unique response to adaptation, taking into account the specific features of the plant. However, under natural conditions, plants are influenced not by one stress factor, but several at once. For example, when exposed to high temperatures, plants experience a lack of water. Recent studies have shown that the response of plants to a combination of drought and heat is unique and cannot be the same as the response of plants to each of these stresses separately. In addition, different stresses may have synergistic or antagonistic effects when combined (Takahashi et al., 2020; Zhang et al., 2020). Therefore, presently it is proposed to consider the combination of stresses as a new type of abiotic stress (Al-Whaibi, 2011).

Such complex polycomponent stress for plants is crude oil pollution of the soil, which has become global (Smith et al., 2016; Dhanwal, 2017; Dickinson, 2017). Drilling and exploitation of crude oil and gas wells, the development of the oil refining industry are among the major factors of environmental contamination (Chizhevskaya et al., 2014). Pollution is virtually inevitable at the sites of crude oil extraction, storage and refining (Zahermand et al., 2020). According to the International Petroleum Industry Environmental Conservation Association, massive plant deaths do not occur during or immediately after oil spills. However, in the medium and long term, the effects of such incidents are extremely negative (Zaher- mand et al., 2020). Decontamination of crude oil fields is an extremely complex task and a relevant issue for all oil production regions. Thus, there is an urgent need for the development of effective and environmentally friendly methods of cleaning the environment from crude oil pollution. Oil pollution is difficult to combat due to its complex chemical nature, high resistance and stability to environmental factors (temperature, solar radiation, humidity, etc.). Physical and chemical methods currently used to clean soils polluted with crude oil are labour intensive and costly, in addition much time is required for soil regeneration and restoration. Physical and chemical methods of cleaning contaminated soils have a one-time effect. They can be used both for one-time urgent cleaning of polluted soils and for prevention of land contamination in the areas that are often exposed to crude oil pollution (Tang et al., 2019). Biological methods have a longer effect and provide for a steady improvement in the environmental situation. Biological degradation of petroleum hydrocarbons can be conducted by bacteria, fungi and plants (Shevchyk \& Romanyuk, 2017; Banarjee, 2018; Ite \& Ibok, 2019). The economic, energyefficient and environmental advantages of biological methods are commonly recognised. Currently, phytoremediation is considered to be the most promising method for cleaning industrial pollution in the developed countries. Plants are known for their ability to create strong resistance to negative environmental factors combined with valuable sedimentary and absorbing properties. They produce a number of adaptive and destructive reactions, the nature and intensity of which corresponds to the ecological state of the environment (Glibovytska \& Mykhailiuk, 2020). 
In the process of phytoremediation of soils, plant roots serve as a source of organic substances that stimulate the development of microorganisms, which in turn destroy hydrocarbons (Gorshkova et al., 2017; Shevchyk \& Romanyuk, 2017). In addition, plants can absorb a number of organic pollutants and transform them into other environmentally safe products (phytotransformation). Considering this, it is increasingly important to study plant participation in the processes of oil components degradation and develop new approaches to phytoremediation of areas polluted with crude oil (Pakharkova et al., 2015; Shevchyk \& Romanyuk, 2017).

It is believed that plants used for phytoremediation should be adjusted to the climatic and soil conditions of contaminated areas (Elekes, 2014; Tang et al., 2019; Peco, 2021) and capable of tolerating stress conditions (Ite \& Ibok, 2019). Basically, phytoremediation should be carried out by means of native plants, especially those that grow in the contaminated areas, rather than foreign or genetically modified species (Nedjimi, 2021). Areas contaminated with crude oil and oil products are inhabited primarily by plant species capable of vegetative reproduction, whereby fully developed plants insensitive to crude oil in the soil are produced (Romaniuk et al., 2018).

Many researchers involved in studies of phytoremediation of oil-contaminated areas recommend the use of herbaceous plants (Hamzah \& Priyadarshini, 2014; Laghlimi et al., 2015; Tang, 2019). The main advantage of grasses is the large fibrous root system, with a big root surface area, and, consequently, a numerous rhizosphere microbiota that plays an important role in soil detoxification (Malik et al., 2021). Grass roots have a large area of contact with the contaminant (Bhat et al., 2017). It is in the root zone of plants that the mass development of microorganisms takes place, including those that utilize or transform organic pollutants (Carvalho et al., 2013; Romaniuk et al., 2018; Tang, 2019). Therefore, the process of crude oil decomposition is faster in areas occupied by plants (under the influence of root secretions of plants and rhizosphere microorganisms) (Romaniuk et al., 2018).

In addition, a large group of perennial grasses can tolerate adverse conditions by means of underground shoots, or rhizomes. Species with long rhizomes are distinguished by high resistance to adverse conditions in ecotopes polluted with crude oil (Dzura et al., 2011). Underground shoots - rhizomes - provide for successful ontogenesis of herbaceous perennials. The family Cyperaceae occupies an important place within the plant system, while the genus Carex L. (Sedges), included in the family, refers to one of the largest genera of flora of Ukraine and the world (Jiménez-Mejías et al., 2015; Danylyk \& Sosnovska, 2016; Danylyk \& Sosnovska, 2017; González-Elizondo et al., 2018; Pereira-Silva et al., 2020; Koopman et al., 2021a). According to various sources, the genus Carex L. includes between 1800 and 2035 species (Danylyk \& Kricsfalusy, 2020; Villaverde et al., 2020; Koopman et al., 2021b).

Carex hirta $\mathrm{L}$. is a perennial herbaceous plant that forms rhizomes with long distinct internodes. It was found (Bunio \& Tsvilynjuk, 2015; Tsvilynyuk et al., 2017; Rusyn \& Hamkalo 2019) that $C$. hirta - an aboriginal herbaceous plant species on oil-contaminated soils of Boryslav - is able to grow on soils polluted with hydrocarbon. Consequently, this species can be potentially used as a phytomeliorant for the remediation of lands polluted with crude oil. This fact determined the choice of $C$. hirta plants for our research.

Crude oil pollution of the soil not only directly influences the plant organism due to the penetration of crude oil components through the root system or leaves and their subsequent inclusion into metabolism, but creates stressful growth conditions by changing water, air, biological and other soil properties. The response of plants to this complex influence has not yet been sufficiently studied (Dickinson, 2017).

One of the first non-specific responses of the plant organism to stress conditions is the formation of compounds (proteins, particularly) which are necessary for the protection of the plant cell (Al-Whaibi, 2011). Abiotic stresses significantly influence plant proteomes including changes in the relative amounts of proteins, their cellular localization, posttranscriptional and posttranslational modifications, the interaction of proteins with other protein molecules and, finally, the biological functions of the proteins (Kosová et al., 2018). Clearly targeted mechanisms for regulation of protein metabolism in plant cells are an extremely important component of the cell responses to abiotic stressors (Al-Whaibi, 2011; Wawrzyńska et al., 2020). Different types of stress conditions may have different responses on components of the protein synthesis system (Mishra et al., 2018). Changes in protein synthesis affect the growth and development of plants and, consequently, influence the effectiveness of phytoremediation. Because of this, the role of proteins in the adaptation of crude oil resistant C. hirta plants was investigated.

\section{Materials and methods}

Field experiments were performed to study the influence of crude oil pollution of the soil on protein metabolism in C. hirta plants. Three phytoremediation sites with a total area of $90 \mathrm{~m}^{2}$ were set at Boryslav crude oil and gas deposit field in the area with a low level of pollution in the southeastern part of Boryslav city at the coordinates: $49^{\circ} 28^{\prime} 09^{\prime \prime}$ N, $23^{\circ} 42^{\prime} 69^{\prime \prime}$ E. Sod-podzolic type of soil is typical for these areas. A site with the background level of soil pollution typical for the industrial city was set as a control (conditional control). A site with soil artificially polluted by crude oil was set as a model soil (experiment).

Three ditches for control and model soils $0.25 \mathrm{~m}$ deep and $1 \times 4 \mathrm{~m}$ in size were dug on the plots and their bottoms were lined with polyethylene film with perforations. Each ditch was filled in with $1000 \mathrm{~kg}$ of soil of $15 \%$ moisture. $50 \mathrm{~kg}$ of crude oil (making $5 \%$ of pollution) were poured into model soils and mixed. In 20 days after the artificial pollution (the required period for evaporation of volatile toxic crude oil products), 150 plants of $C$. hirta of virgin age selected from a homogeneous (according to ecological conditions) clean environment were planted in the soil of each ditch. They were planted in rows in a checkerboard pattern in holes 10-15 cm deep keeping the distance between plants at 15-25 cm (Bunio, 2014a). Soil moisture was maintained within $60 \%$ of the total moisture content.

25 plants were randomly selected from each site. Sampling was performed on the 30th (rosette phase) day of growth of $C$. hirta plants, which corresponds to the 50th day of destruction of crude oil in the soil.

The content and electrophoretic spectrum of proteins were determined in the leaves, rhizomes and roots of $C$. hirta plants. The total protein content was determined by the Bradford method (Bradford, 1976). To determine the qualitative composition of proteins, plant organs were frozen in liquid nitrogen. Frozen tissue samples were ground in a porcelain mortar under constant cooling with liquid nitrogen to a powdery state. The resulting homogenate was thawed, the proteins were extracted with constant stirring at $+4^{\circ} \mathrm{C}$ for 20 min with water containing protease inhibitors in RIPA buffer of the following composition: $50 \mathrm{mM}$ Tris- $\mathrm{HCl}$ (pH 7.5), 1\% NP-40, 0.5\% DOC, 0.1\% SDS, 5 mM EDTA, $1 \mathrm{mM}$ PMSF, $5 \mathrm{mM}$ benzamidine. The insoluble fraction was precipitated by centrifugation at $12,000 \mathrm{rpm}$ for $25 \mathrm{~min}$ and the supernatant was transferred into a clean tube. $25 \%(\mathrm{~V} / \mathrm{V})$ of $50 \%$ trichloroacetic acid was added to the supernatant, then it was frozen at $-70{ }^{\circ} \mathrm{C}$ for $60 \mathrm{~min}$, thawed, precipitated by centrifugation at $12,000 \mathrm{rpm}$ for $25 \mathrm{~min}$. Then the precipitate was washed three times with $80 \%$ chilled acetone, dried and dissolved in RIPA buffer. The obtained samples were frozen in liquid nitrogen and stored until subsequent use at $-70{ }^{\circ} \mathrm{C}$. For electrophoretic analysis, samples were previously normalized to protein concentration, heated at $95^{\circ} \mathrm{C}$ for $5 \mathrm{~min}$ in Laemmli buffer (62.5 mM Tris-HCl, pH 6.8, 1 mM EDTA, $2 \%$ SDS, $5 \%$ mercaptoethanol, $10 \%$ glycerin, $0.4 \%$ bromophenol blue) (Laemmli, 1970). Proteins were separated in a denaturing 12\% SDSPAGE in a Tris- $\mathrm{HCl}$ buffer system. $50 \mu \mathrm{g} / \mathrm{mL}$ of protein was applied. A set of standard proteins with a molecular weight of 200, 150, 100, 90, $70,60,50,40,30$ and $20 \mathrm{kD}$ was used a marker.

Electrophoregrams were painted with Coomasie R-250. Stained electrophoregrams were photographed, comparative densitometric analysis of proteins was performed with the program Gelpro 32. The protein content was determined in conventional units corresponding to each zone on the blots. Analysis of samples of each variant was performed three times.

Detection of abscisic acid (ABA) was performed by HPLC-MS method on liquid chromatograph Agilent 1200 LC with diode-matrix detector G 1315 B (USA) on a column Eclipse XDB-C18 $4.6 \times 250$ with a particle size of $5 \mu \mathrm{m}$ (The methodological recommendations..., 1988).

Data were analyzed using two-tailed Student's t-tests and differences were deemed significant at $\mathrm{P}<0.05$. 


\section{Results}

On the 30th day of plant growth on crude oil polluted soil, the protein content was decreased by $20 \%$ with regard to control, and in underground organs it was increased by $7 \%$ and $8 \%$ with regard to control plants in roots and rhizomes, respectively (Fig. 1).

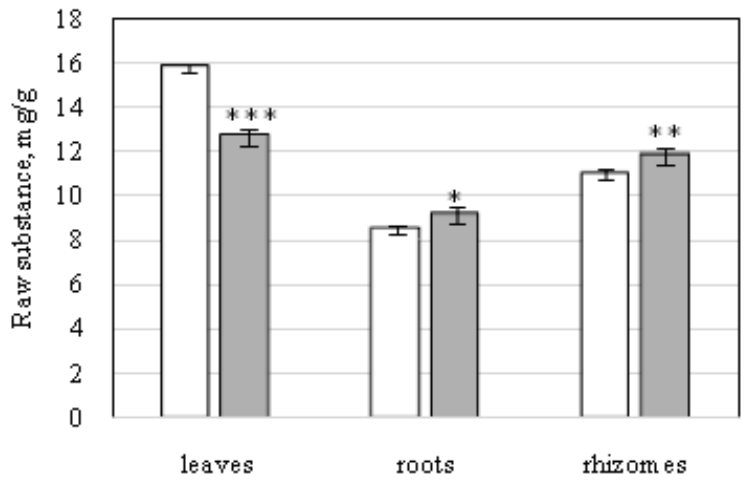

Fig. 1. Protein content in the organs of 30 days old Carex hirta plants under influence of crude oil pollution of the soil ( $\mathrm{mg} / \mathrm{g}$ of raw substance): white column - background soil (control); grey column - model soil

(experiment $-5 \%$ crude oil); the difference between control and experimental plants is statistically reliable $\left({ }^{*}-\mathrm{P}<0.05,{ }^{* *}-\mathrm{P}<0.01,{ }^{* * *}-\mathrm{P}<0.001\right)$

Simultaneously with changes in protein content, changes in its quailtative composition were observed. The results of electrophoretic studies showed that the spectra of proteins in plant organs of $C$. hirta under normal and stressful conditions had qualitative and quantitative differences, particularly, in the composition of components and the intensity of individual tracks (Fig. 2). At the same time, identical proteins are present in the profile of proteins synthesized during the growth of $C$. hirta plants on background (normal conditions) and model (stress conditions) soils (Fig. 2).
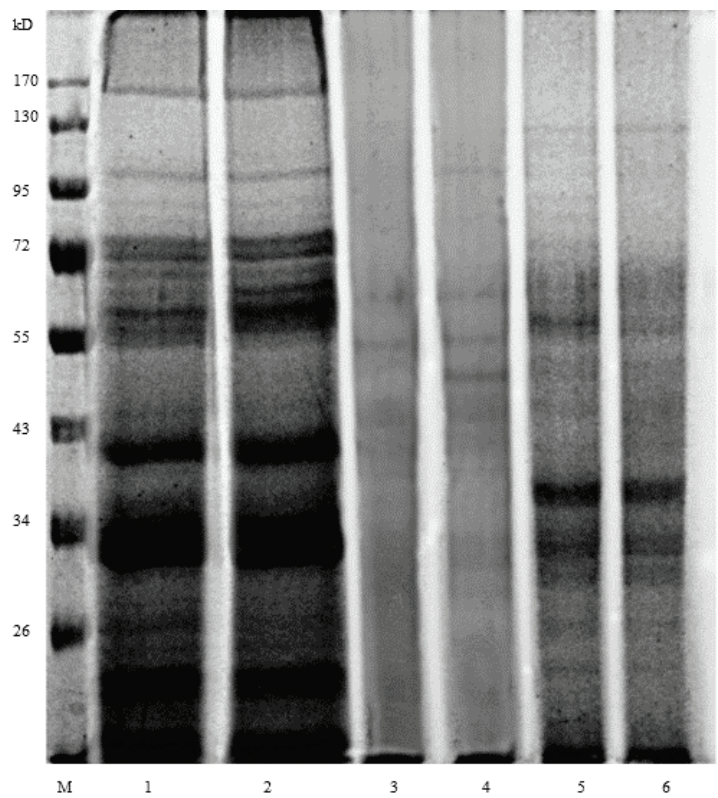

Fig. 2. Electrophoregrams of proteins of Carex hirta 30 days old plants on 30th day of growth on crude oil polluted soil (5\%):

$\mathrm{M}$ - markers of molecular weight; 1 - control (leaves);

2 - experiment (leaves); 3 - control (roots); 4 - experiment (roots);

5 -control (rhizomes); 6 - experiment (rhizomes)

Low molecular weight polypeptides (sHsp, 31-45 kD) were detected in electrophoregrams of all analyzed $C$. hirta plant organs both in control and under conditions of crude oil pollution of the soil, which confirms their participation in plant growth and development. Also, polypeptide sHsp with a molecular weight of $22 \mathrm{kD}$ was found in leaves and rhizomes, however, such polypeptide was absent in the roots.
Under conditions of growth on crude oil polluted soil, sHsp proteins with the same molecular weight as in the control variant, but with some difference, were synthesized in the leaves of $C$. hirta plants. Proteins with a molecular weight of $26 \mathrm{kD}$ were detected in the control, while in experimental plants $-27 \mathrm{kD}$ (Table 1$)$.

We found a 2.2-fold increase of ABA content in the leaves of $C$. hirta plants that grew on crude oil polluted soil (Fig. 3). At the same time the protein with a molecular weight of $27 \mathrm{kD}$ was detected (Table 1).

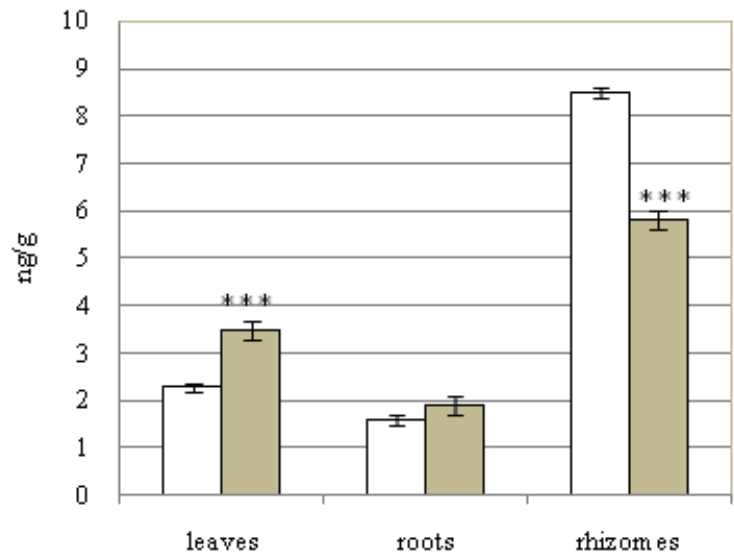

Fig. 3. The content of $A B A(n g / g$ of raw substance) in the organs of $\mathrm{Ca}$ rex hirta plants on the 30th day of growth on crude oil polluted soil (5\%):

white column - background soil (control); grey column - model soil

(experiment $-5 \%$ crude oil); the asterisks indicate that there is statistically significant of ABA in plants $(* * *-\mathrm{P}<0.001)$

Under conditions of crude oil polluted soil, up to 1.5 times more proteins with molecular weights of $41,57,73$ and $77 \mathrm{kD}$ were synthesized in sedge leaves (Table 1). Protein with Mr $60 \mathrm{kD}$ was synthesized in $C$. hirta leaves both normally and under the influence of crude oil pollution but in the case of pollution, its expression was increased by $57 \%$. There was also a significant increase up to 2.5 and 3.5 times of proteins with $\mathrm{Mr} 64 \mathrm{kD}$ and $85 \mathrm{kD}$, respectively, during the growth of $C$. hirta plants on crude oil polluted soil. With regard to the control experiments, there was a slight decrease in the content of proteins with $\mathrm{Mr} 22,25,32,69,104$ and $163 \mathrm{kD}$. The content of proteins with $\mathrm{Mr} 28,45,91 \mathrm{kD}$ in the leaves of plants growing on crude oil polluted soil had more than halved.

\section{Table 1}

The relative protein content in the leaves of Carex hirta plants on the 30th day of growth on crude oil polluted soil (\%); total mass proteins was recorded and used to calculate the relative mass (expressed as a percent of the value for the same line a marker proteins, set to $100 \%$ )

\begin{tabular}{ccc}
\hline Mr, kD & Background soil (control) & Model soil (experiment) \\
\hline 163 & 12.15 & 10.48 \\
104 & 6.41 & 6.11 \\
91 & 2.16 & 1.09 \\
85 & 8.80 & 31.54 \\
77 & 18.92 & 25.12 \\
73 & 22.40 & 25.43 \\
69 & 14.71 & 12.65 \\
64 & 12.81 & 31.86 \\
60 & 31.87 & 50.14 \\
57 & 24.66 & 29.66 \\
45 & 7.79 & 2.76 \\
41 & 47.05 & 48.11 \\
32 & 55.02 & 48.36 \\
28 & 2.33 & 1.09 \\
27 & 0.00 & 4.00 \\
26 & 12.14 & 0.00 \\
25 & 6.59 & 6.37 \\
22 & 42.15 & 31.79 \\
\hline
\end{tabular}

The areas of the leaf plates varied almost along a symmetrical parabolic curve. Under the influence of crude oil, the descending part of the curve was steeper (Fig. 4).

Analysis of the fractional protein composition of the rhizomes of C. hirta plants under the influence of crude oil pollution revealed less significant, in comparison with the leaves, differences between control and 
experimental plants. There were proteins with $\mathrm{Mr} 93$ and $120 \mathrm{kD}$ under normal conditions (control) and $118 \mathrm{kD}$ in the experiment (Table 2). All other proteins detected by us were of the same electrophoretic mobility. Under the influence of crude oil polluted soil, a slight increase in the amount of low molecular weight proteins, most likely belonging to the Hsp 45, 65, 104 and $128 \mathrm{kD}$ families, was observed in the rhizomes of C. hirta. The protein content of $\mathrm{Mr} 41 \mathrm{kD}$ in the rhizomes of the experimental plants increased almost 6 times.

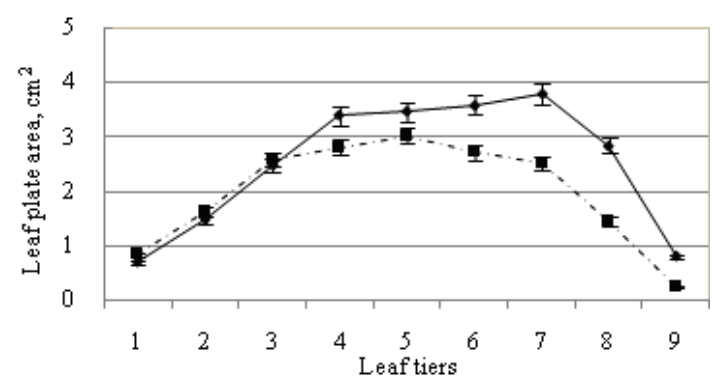

Fig. 4. Change in the leaf plates area of Carex hirta plants on the 30th day of growth on crude oil polluted soil (5\%): background soil (control) and model soil (experiment $-5 \%$ crude oil); values are means of three replicates $\mathrm{x} \pm \mathrm{SD}(\mathrm{n}=3,25$ plants per repetition)

\section{Table 2}

The relative amount of protein in the rhizomes of Carex hirta plants on the 30th day of growth on crude oil polluted soil (\%); total mass proteins was recorded and used to calculate the relative mass (expressed as a percent of the value for the same line a marker proteins, set to $100 \%$ )

\begin{tabular}{ccc}
\hline Mr, kD & Background soil (control) & Model soil (experiment) \\
\hline 128 & 2.82 & 3.99 \\
120 & 1.79 & 0.00 \\
118 & 0.00 & 1.11 \\
104 & 1.30 & 1.48 \\
93 & 1.51 & 0.00 \\
85 & 1.26 & 0.36 \\
76 & 2.26 & 0.83 \\
65 & 10.96 & 11.10 \\
56 & 16.59 & 9.02 \\
50 & 5.03 & 4.87 \\
45 & 4.30 & 5.91 \\
41 & 0.46 & 2.92 \\
37 & 40.87 & 30.94 \\
34 & 24.78 & 19.08 \\
33 & 23.71 & 19.63 \\
30 & 11.94 & 8.97 \\
27 & 5.88 & 3.35 \\
23 & 9.74 & 4.32 \\
\hline
\end{tabular}

Proteins with a corresponding molecular weight of $56 \mathrm{kD}$, which probably belong to the HSP 60 family, were found under control and stress conditions, and, moreover, after growth on crude oil polluted soil, their content in the rhizome decreased almost two times (Table 2).

The amount of proteins with $\mathrm{Mr} 76 \mathrm{kD}$ and $85 \mathrm{kD}$ in the rhizomes of experimental $C$. hirta plants, belonging to the families HSP 70 and HSP 90, was 2.7 and 3.5 times less, respectively, compared to the control, which may be one of many ways of adaptation of plants to local conditions of existence.

In plants grown on crude oil polluted soil, proteins with a molecular weight close to 50,53 , and $105 \mathrm{kD}$ were synthesized in the roots, which was not detected in the roots of control plants (Fig. 2, Table 3). The protein content in the roots with $\mathrm{Mr} 39$ and $64 \mathrm{kD}$ decreased more than 1.5 times compared to the control. An increase by $23 \%$ in the $43 \mathrm{kD}$ protein content in the roots of experimental plants was observed. The thickening of C. hirta roots under conditions of growth on crude oil polluted soil was observed (Fig. 5).

\section{Discussion}

The adaptation syndrome includes a decrease of the intensity of total protein synthesis, which was exactly found in the leaves during the growth of $C$. hirta plants under conditions of crude oil pollution. This phenome- non may be not so much the result of cell damage as a typical manifestation of the protective reaction, and partial inhibition of protein synthesis reduces the intensity of destructive processes (Waters \& Vierling, 2020). It was found that one of the primary responses to stress is the selective degradation of the protein-synthesizing apparatus, proteosomal degradation of proteins and the formation of the necessary compounds for the urgent protection of plant cells (Katz \& Orellana, 2012). At the same time, it is important to preserve the structure of protein molecules and prevent their aggregation (Al-Whaibi, 2011). Termination or inhibition of protein synthesis, which is a characteristic response of plants to stressors, is an imperfect adaptation aiming to protect quickly the plant (although, in short-term) from death under adverse factors and to initiate the formation or mobilization of specialized mechanisms for long-term resistance. Most likely, all the power of the plant was directed to protection of the underground organs which are under greater stress load. We observed an increased protein metabolism in these organs. It is believed that the stress response is transitory and ensures the transition of the plant from normal to stressful metabolism by blocking non-essential metabolic pathways and triggering protective mechanisms, especially shock response systems (Waters \& Vierling, 2020; Li et al., 2021). The increase of protein content in roots and rhizomes may be a consequence of their enzymatic adaptation and compaction of membrane structures in order to protect cells against the damaging factor. One of the possible detoxification reactions of pollutants is an increase of the content of proteins that are able to regulate cell osmosis (Murzin et al., 2011). Experimental data cited in the literature also suggest that protein accumulation is an important part of the mechanisms of stability in the event of various adverse factors (Jaber et al., 2013; Emad et al., 2018).

\section{Table 3}

The relative amount of protein in the roots of Carex hirta plants on the 30 th day of growth on crude oil polluted soil (\%); total mass proteins was recorded and used to calculate the relative mass (expressed as a percent of the value for the same line a marker proteins, set to $100 \%$ )

\begin{tabular}{ccc}
\hline $\mathrm{Mr}, \mathrm{kD}$ & Background soil (control) & Model soil (experiment) \\
\hline 105 & 0.00 & 2.54 \\
64 & 6.89 & 4.29 \\
54 & 5.02 & 4.38 \\
53 & 0.00 & 2.62 \\
50 & 0.00 & 9.05 \\
43 & 5.82 & 7.14 \\
39 & 2.53 & 1.46 \\
32 & 5.40 & 5.16 \\
\hline
\end{tabular}

There are three stages of the cellular response to abiotic stress: transition of signals to the nucleus, interaction with genes; induction or repression of mRNA translation; formation of stress proteins (Lario \& Parra, 2013). Heat shock proteins (HSP) encoded in the nuclear, chloroplast and mitochondrial genomes (Ul Hag et al., 2019) are synthesized in the cytoplasm, transported to all parts of the cell, to the nucleus and nucleolus, in mitochondria and chloroplasts, in the endoplasmic reticulum, even extracellular matrix, where they perform a protective function. Each family of HSP is encoded, as a rule, by several close genes, however regulation of their activity can differ. Also, the newly synthesized protein may be modified under certain circumstances and this may affect its molecular weight (Stoychev, 2013). HSPs protect other proteins against irreversible damages, prevent their aggregation in the cytosol and mitochondria, provide the correct conformation, which is necessary to maintain functional activity. The expression of these proteins is accompanied by stabilization of the cytoskeleton, in particular actin, which restores cellular structure. After the stress, the synthesis of proteins characteristic for the usual conditions of existence is resumed and the mRNA of stress proteins are destroyed. The ubiquitin protein provides proteolytic destruction of damaged HSPs (Liu \& Charng, 2012; Tian et al., 2021; Zhao et al., 2021). Each stage of plant response to stress can be characterized by a unique protein composition. The phase of acclimatization and response to stress and adaptation of plants against adverse factors is accompanied by the synthesis of high(60-100 kD) and low molecular weight (15-45 kD) stress proteins: chaperones, enzymes with antioxidant activity, protective proteins (LEA, PR) (Kosova et al., 2018). Stress proteins play an important role in maintaining 
of cellular homeostasis under adverse conditions, in protecting and restoring the balance after stress (Al-Whaibi, 2011; Qu et al., 2013; Chen et al., 2014). The synthesis of stress proteins is accompanied by ultrastructural changes at the level of organelles. There is a breakdown of polysomes that synthesize proteins inherent to the usual conditions of existence and formation of polysomes that synthesize heat shock proteins, segregation of nucleoli, disruption of organelle membranes and increase their contacts (Lario et al., 2013).

A

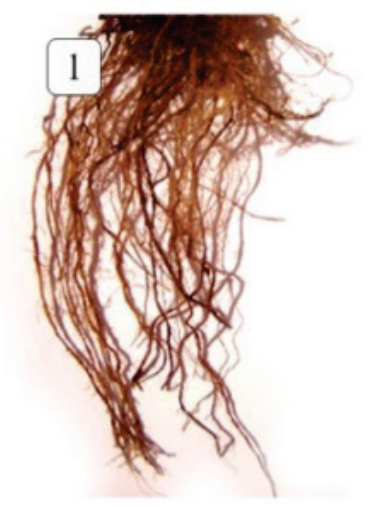

B

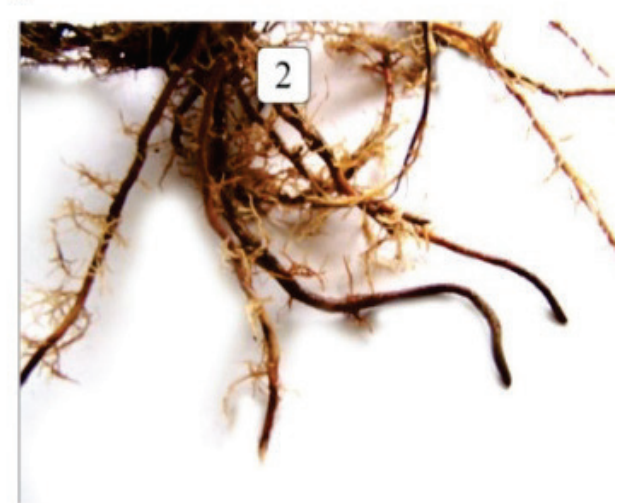

$\mathrm{C}$
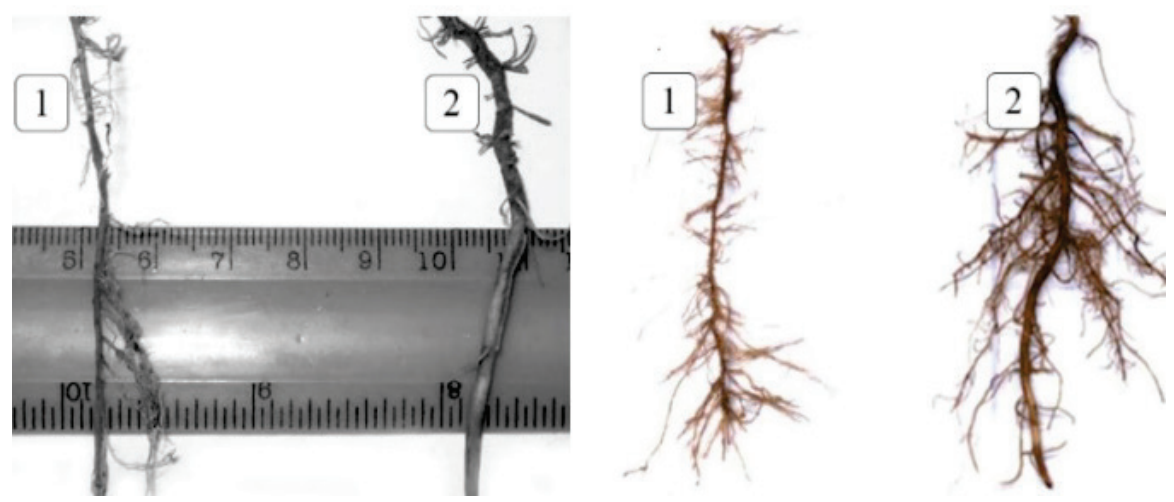

Fig. 5. The root system of Carex hirta plants on the 30 th day of growth on crude oil polluted soil ( $5 \%$ of pollution): $A$-root system; $B, C$-individual fragments of roots; 1 -control, 2 - model soil

sHsp were detected in all plant organs of $C$. hirta. Their synthesis is associated with the development of resistance to stress. Proteins with a molecular weight from 15 to $45 \mathrm{kD}$ are synthesized in the cells of all eukaryotes and are called low molecular weight heat shock proteins (small heat shock proteins, sHsp) (Mishra et al., 2018). Not only heat stress triggers sHsp gene expression and protein synthesis. Plants are characterized by an extraordinary diversity of $\mathrm{sHsp}$ due to the need for rapid adaptation to drastic changes in living conditions (Al-Whaibi, 2011; Mishra et al., 2018). The correlation between sHsp synthesis and stress response became the basis for formulating the hypothesis of the protective role of low molecular weight HSP. The mechanism - how sHsp act as cellular protectors - is not yet fully understood but it is clear that sHsp are capable of performing the function of ATP-independent chaperones binding partially denatured protein substrates and preventing their irreversible aggregation (Tian et al., 2021). Studies with purified plant CI (cytosolic class I), CII (cytosolic class II) and CP (chloroplast) sHSPs have confirmed this assumption. Upon completion of influence of damaging factors and restoration of normal conditions, sHsp are detected in the cell within the following $30-50 \mathrm{~h}$, so it is assumed that the presence of sHsp is an important factor in the recovery of the plant organism (Mishra et al., 2018; Waters \& Vierling, 2020).

Plants differ in the multiplicity of sHsp and their high intensity of synthesis under various stresses (Hasanuzzaman et al., 2013; Waters \& Vierling, 2020). Low molecular weight sHsp biosynthesis indicates a protective function of these polypeptides under dehydration or rehydration (Cheng et al., 2008). The accumulation of low molecular weight hydrophilic proteins maintains the high water holding capacity of the cytoplasm under drought conditions. These proteins bind significant amounts of water with hydrate shells (Waters \& Vierling, 2020). It is known that the synthesis of leaf-specific $27 \mathrm{kD}$ protein is caused by water deficiency.
Water stress causes an increase in the content of so called stress hormonesabscisic acid (ABA), jasmonic acid and ethylene. ABA, for example, inhibits the synthesis of mRNA and their corresponding proteins which are typical under normal conditions, and induces the activity of genes and hence the synthesis of specific proteins, including $27 \mathrm{kD}$ protein (Liu et al., 2016; Kamba et al., 2018; Li et al., 2021).

$32 \mathrm{kD} \mathrm{PsbO}$ protein belongs to the triad of external proteins of Photosystem II (PSII). PSII possesses a membrane protein complex consisting of three tightly bound external proteins: PsbO (Mr 32-33 kD), PsbP (Mr 23-24 kD) and PsbQQ (Mr 17-18 kD) (Sasi et al., 2018). PsbO is one of the external PSII subunits located on the lamellar side of the thylakoid membrane and protects PSII from photodamage (Roose et al., 2016; Gururani et al., 2017). It is known that PsbO is a highly conserved protein. It is detected in $60-80 \%$ of higher plants and algae and about $40 \%$ of lower plants and cyanobacteria (Roose et al., 2016). Kosmala et al. (2009) noted a decrease in the amount of PsbO under cold stress, which affected the functional state of PSII and led to a decrease in the intensity of photosynthesis. A similar decrease in the productivity of photosynthesis was also found under other stresses (Dwyer et al., 2012; Gururani et al., 2017; Alyammahi \& Gururani, 2020). Reduction in the content of PsbO also has a negative effect on rhizogenesis, accelerates the aging of the plant organism, stimulates tuber formation (Gururani et al., 2017; Alyammahi \& Gururani, 2020). In our opinion, accelerated aging of $C$. hirta leaves during growth on crude oil polluted soil can be explained by the decrease in PsbO content, which was estimated by the change of leaf plates area on different tiers. Under the influence of crude oil, the descending part of the curve was steeper. This indicates on faster aging of leaves in plants that grew on crude oil polluted soil (Bunio et al., 2017).

Increased content of sHSP in the rhizomes may indicate significant stress load on this organ since chaperones are capable of forming bonds 
with partially destroyed or denatured proteins and thus prevent their irreversible conformational changes and aggregation (Waters \& Wierling, 2020). For example, it is known that the $33 \mathrm{kD}$ Hsp protein content in plants increases in hydrophobic environments (Gow-Jen et al., 2011; Taguchi et al., 2020).

One of the biological functions of low molecular weight proteins is that they are capable of binding phytohormones and thus may affect the growth processes of plants and their adaptation to stressful conditions (Fernandes et al., 2013; Sliwiak et al., 2018). By stimulating the expression of individual genes and the synthesis of new polypeptides, ABA promotes the formation of protective reactions and increases plant resistance (Osakabe et al., 2014). ABA participates in the formation of responses acting as a trigger for the launch of signaling cascades. It has been found that a key role in signal transduction and the functioning of ion transport membrane systems in response to stress belongs to phosphatase and kinase ABA receptor proteins (Osakabe et al., 2014; Ali et al., 2020; $\mathrm{Li}$ et al., 2021). An increase in the concentration of endogenous ABA is a signal for the expression of genes sensitive to cold stress (Li et al., 2021). ABA activates COR genes (cold regulated) which include RAB (ABAresponsive), DHN (dehydrins) and genes from the family LEA (late embryogenesis abundant), whose products are directly involved in the formation of plant resistance against the action of low temperatures ( $\mathrm{Li}$ et al., 2021). There were significant changes in the balance of other investigated phytohormones in both above-ground and underground organs of $C$. hirta plants under the influence of crude oil. The nature of these changes was not the same in different organs and depended on the impact of crude oil load on these organs (Bunio, 2014b).

Proteins of the HSP 60 family are found in mitochondria and chloroplasts in stress-induced and constitutive states (Al-Whaibi, 2011). Their main function is to provide conformational rearrangements of mitochondrial and chloroplast polypeptides. A significant increase of the protein with $\mathrm{Mr} 64 \mathrm{kD}$ in the leaves, which belongs to the HSP $70 \mathrm{kD}$ family, plays an important role in preventing aggregation and promotes the rearrangement of inactive proteins. It is well known that proteins of the HSP $70 \mathrm{kD}$ family are mainly localized in the cytoplasm, where both stressinduced and constitutive polypeptides are expressed (Al-Whaibi, 2011), they are also present in the nucleus and mitochondria. This may indicate on a protective role of these proteins against adverse factors (Ul Haq et al., 2019).

The roots play a key role in the response of plants to water stress (WS). They are involved in the perception of WS and in signal transmission to the leaf (Bhakti et al., 2018). Proteins from the HSP 70kD (except $64 \mathrm{kD}$ ) and $90 \mathrm{kD}$ families were not detected in the roots of either control or experimental plants of $C$. hirta. The reasons for not detecting HSP 70 in the organs of $C$. hirta plants under normal conditions or under conditions of pollution are not yet clear and require further investigation. Probably, the growth of $C$. hirta on soils with chronic crude oil loading (background soil) and soils with additionally added crude oil (model soil) affects the stability of HSP 70 mRNA, leading to inhibition of HSP 70 synthesis. At the same time, the fact cannot be excluded that the observed changes may be related to the natural, extremely low concentration (outside the sensitivity of the method) of HSP 70 in C. hirta. Although the induction of the synthesis of this stress protein is one of the universal, widespread components of the stress response to adverse conditions, it does not play an important role in the mechanism of stress adaptation in $C$. hirta. In some species, this process is reduced or not detected. Such phenomenon is known for some specialized and endemic species that are narrowly adapted to certain living conditions (Drozdova et al., 2019). The absence of induction of Hsp 70 in the roots of $C$. hirta plants may indicate their narrow specialization to certain living conditions (Kozeko et al., 2011). C. hirta is a mesohygrophyte usually growing in areas where ground waters are situated close to the surface. This species is found on sandy and clay substrates with $\mathrm{pH}$ from strongly alkaline to neutral and weakly acidic. The area of its distribution is not continuous, uneven, which reveals another specific feature of $S$. hirta - a complicated living strategy. This species does not withstand competition with other species, so it grows on short-lived ecotopes - inhabits artificial dumps along roads and railways, crude oil polluted areas. The $53 \mathrm{kD}$ protein is called the protector of the genome due to its effect on DNA repair. It acts as a mediator between cell proliferation, stress and cell death (Levine \& Oren, 2009; Brady \& Attardi, 2010). Expression of $53 \mathrm{kD}$ in Arabidopsis thaliana induced premature aging and distortion of lateral shoots, the formation of thick stems, caused by increased homologous recombination of DNA. Hsp53 $\mathrm{kD}$ is also a super-suppressor of tumours (Ma et al., 2016). We assume that the thickening of $C$. hirta roots under conditions of growth on crude oil polluted soil is caused by an increase of the concentration of this protein.

\section{Conclusion}

Thus, the obtained results allow us to conclude that a possible element in the process of adaptation of $C$. hirta plants to combined stress - conditions of crude oil polluted soil - may be the synthesis of stress proteins: high molecular weight of more than $60 \mathrm{kD}$ and low molecular weight not exceeding $22-45 \mathrm{kD}$.

While growing on crude oil polluted soil, the roots and rhizomes of C. hirta plants undergo more stress load than the leaves, as evidenced by the greater protein content in these organs. However, the increased protein content in these organs may as well indicate the outflow of this metabolite from the leaves where its decrease was noticed.

Under conditions of crude oil pollution of the soil, the synthesis of ABA increased in the leaves of $C$. hirta plants which, in turn, caused faster leaf aging and the synthesis of a specific protein with $\mathrm{Mr} 27 \mathrm{kD}$. ABA restricts plant growth with the aim of coordinainge plant adaptation to stressful conditions.

\section{References}

Ali, A., Pardo, J. M., \& Yun, D.-J., (2020). Desensitization of ABA-signaling: The swing from activation to degradation. Frontiers in Plant Science, 11, 379.

Al-Whaibi, M. H. (2011). Plant heat-shock proteins: A mini review. Journal of King Saud University-Science, 23, 139-150.

Alyammahi, O., \& Gururani, M. A. (2020). Chlorophyll-a fluorescence analysis reveals differential response of photosynthetic machinery in melatonin-treated oat plants exposed to osmotic stress. Agronomy, 10(10), 15-20.

Banarjee, P. (2018). Phytoremediation: Using natural strength for curing nature. Acta Scientific Agriculture, 2(12), 144-153.

Bhakti, P., Negri, A. S., Failla, O., Scienza, A., \& Espen, L. (2018). Root proteomic and metabolic analyses reveal specific responses to drought stress in differently tolerant grapevine rootstocks. BMC Plant Biology, 18, 126-152.

Bhat, R. A., Dervash, M. A., Mehmood, M. A., Rashid, A., Bhat, J. I. A., \& Singh, D. V. (2017). Mycorrhizae: A sustainable industry for plant and soil environment. In: Mycorrhiza - nutrient uptake, biocontrol, ecorestoration. Издательство, город. Рр. 473-502.

Bradford, M. M. (1976). A rapid and sensitive method for the quantitation of microgram quantities of protein utilizing the principle of protein-dye binding. Analytical Biochemistry, 72, 248-254.

Brady, C. A., \& Attardi, L. D. (2010). p53 at a glance. Journal Cell Sci, 123, 2527 2532.

Bunio, L. V., \& Tsvilynjuk, O. M. (2015). Specific features of morphogenesis of sedge (Carex hirta L.) on oil-contaminated soil. Contemporary Problems of Ecology, 8, 660-667.

Bunio, L., Vojtenko, L., Musatenko, L., Tsvilynjuk, O., \& Terek, O. (2014b). Hormonalnyi status roslyn Carex hirta L., vyroshchenykh na hruntakh zabrudnenykh naftoiu [Hormonal status of Carex hirta L. plants grown on oil polluted soil]. Visnyk of Lviv University, Series Biology, 67, 274-282 (in Ukrainian).

Bunio, L. V., Tsvilinjuk, O. M., \& Terek, O. I. (2017). Zmina morfohenezu pidzemnykh orhaniv roslyn Sarex hirta L. za umov rostu na naftozabrudnenynomu grunti [Changes of morphogenesis undersoil organs of Carex hirta L. plants growing on the oilcontaminated soil]. Studia Biologica, 11 (3-4), 51-52 (in Ukrainian).

Carvalho, A., Nabais, C., Roiloa, S. R., \& Rodriguez-Echeverria, S. (2013). Revegetation of abandoned copper mines: The role of seed banks and soil amendments. Web Ecology, 13, 69-77.

Chen, X., Lin, S., Liu, Q., Huang, J., Zhang, W., Lin, J., Wang, Y., Ke, Y., \& He, H. (2014). Expression and interaction of small heat shock proteins (sHsps) in rice in response to heat stress. Biochim Biophys Acta, 1844, 818-828.

Chizhevskaya, M. V., Mironova, V. A., \& Fomina, N. V. (2014). Rezultaty primenenija smeshannykh kultur pochvennykh vodoroslej dlya bioremediatsii pochv, zagriaznennykh nefteproduktami [The results of application of mixed cultures of soil algae for bioremediation of soils polluted by oil products]. Vestnik KrasGAU, Ecology, 12, 94-98 (in Russian). 
Danylyk, I., \& Kricsfalusy, V. V. (2020). Phytogeographical differentiation of the genus Carex (Cyperaceae) in Saskatchewan, Canada. Journal of Botany, 30(1), $1-21$.

Danylyk, I., \& Sosnovska, S. (2016). Strukturno-funktsionalni ta adaptatsijni peretvorennia v populiatsijakh vydiv rodu Carex L. u karpatskomu, podilskomu ta zakhidnopoliskomu rehionakh Ukrajiny v umovakh antropopresiji [Structural and functional changes and adaptive potential of Carex L. populations in the Ukrainian Carpathians and in the Western Polissia and Podillia regions (Ukraine) under anthropogenic pressure]. Naukovi Osnovy Zberezhennia Biotychnoi Riznomanitnosti, 7(14), 157-180 (in Ukrainian).

Danylyk, I., \& Sosnovska, S. (2017). Population structure of Carex dioica L. (Cyperaceae) in Ukraine under different growth conditions. Biodiversity: Research and Conservation, 46, 19-33.

Dhanwal, P., Kumar, A., Dudeja, S., Chhokar, V., \& Beniwal, V. (2017). Recent advances in phytoremediation technology. Advances in Environmental Biotechnology, ?????, 227-241.

Dickinson, N. (2017). Phytoremediation. Encyclopedia of Applied Plant Science, 3, 327-331.

Drozdova, P., Bedulina, D., Madyarova, E., Rivarola-Duarte, L., Schreiber, S., Stadler, P. F., Luckenbach, T., \& Timofeyev, M. (2019). Description of strongly heat-inducible heat shock protein 70 transcripts from Baikal endemic amphipods. Scientific Reports, 9, 8907.

Dwyer, S., Chow, W., Yamori, W., Evans, J., Kaines, S., Badger, M., \& Caemmerer, S. (2012). Antisense reductions in the PsbO protein of photosystem II leads to decreased quantum yield but similar maximal photosynthetic rates. Journal Experimental Botani, 63(13), 4781-4795.

Dzhura, N. (2011). Perspektyvy fitoremediatsiji naftozabrudnenykh gruntiv roslynamy Faba bona Medic. (Vicia faba L.) [Prospects of oil polluted soils phytoremediation by Faba bona Medic. (Vicia faba L.) plants]. Visnyk of the Lviv University, Series Biology, 57, 117-124 (in Ukrainian).

Elekes, C. C. (2014). Eco-technological solutions for the remediation of polluted soil and heavy metal recovery. In: Hernández-Soriano, M. C. (Ed.). Environmental risk assessment of soil contamination. InTech, Rijeka. Pp. 309-335.

Emad, J., Kovalchuk, A., Raffaello, T., Keriö, S., Teeri, T., \& Asiegbu, F. O. (2018) A gene encoding scots pine antimicrobial protein Sp-AMP2 (PR-19) confers increased tolerance against Botrytis cinerea in transgenic tobacco. Forests, 9(1), 10.

Fernandes, H., Michalska, K., Sikorski, M., \& Jaskolski, M. (2013). Structural and functional aspects of PR-10 proteins. FEBS Journal, 280(5), 1169-1199.

Glibovytska, N., \& Mykhailiuk, Y. (2020). Phytoindication research in the system of environmental monitoring. Ecological Sciences, 28, 111-114 (in Ukrainian).

González-Elizondo, M. S., Reznicek, A. A., \& Tena-Flores, J. A. (2018). Cyperaceae in Mexico: Diversity and distribution. Botanical Sciences, 96(2), 305-331.

Gorshkova, O. G., Gudzenko, T. V., Voliuvach, O. V., Beliaeva, T. O., \& Konup, I. P. (2017). Oil oxidization and bio-safactants production by strains of $P$. fluorescens ONU541 and B. megaterium ONU542. Microbiology and Biotechnology, 2, 61-71 (in Ukrainian).

Gow-Jen, S., Lee-Feng, C., \& Rong-Long, P. (2011). The extrinsic proteins of an oxygen-evolving complex in marine diatom Cylindrotheca fusiformis. Botanical Studies, 52, 161-171.

Gururani, M. A., Venkatesh, J., Ghosh, R., Strasser, R. J., Ponpandian, L. N., \& Bae, H. (2017). Chlorophyll-a fluorescence evaluation of PEG-induced osmotic stress on PSII activity in Arabidopsis plants expressing SIP1. Plant Biosyst. International Journal Dealing with all Aspects of Plant Biology, 3504, 1-8.

Hamzah, A., \& Priyadarshini, R. (2014). Identification of wild grass as remediator plant on artisanal gold mine tailing. Plant Science International, 1, 33-40.

Hasanuzzaman, M., Nahar, K., Alam, M., Roychowdhury, R., \& Fujita, M. (2013). Physiological, biochemical, and molecular mechanisms of heat stress tolerance in plants. International Journal Molecular Sciences, 14(5), 9643-9684.

Ite, A. E., \& Ibok, U. J. (2019). Role of plants and microbes in bioremediation of petroleum hydrocarbons contaminated soils. International Journal of Environmental Bioremediation and Biodegradation, 7(1), 1-19.

Jaber, E., Sooriyaarachchi, S., Covarubias, S., Ubhayasekera, A. W., Mowbray, S. L., \& Asiegbu, F. O. (2013). Molecular characterization of the expression and regulation of Scots pine (Pinus sylvestris L.) antimicrobial proteins (AMPs). In $\mathrm{XIII}$ Conference root and butt rot of forest trees. Firenze University Press, Firenze. Pp. 26-28.

Jiménez-Mejías, P., Rodríguez-Palacios, G. E., Amini-Rad, M., \& Martín-Bravo, S. (2015). Taxonomic notes on some problematic Carex (Cyperaceae) names from SW Asia. Phytotaxa, 219(2), 183-189.

Kamba, P. F., Dickson, D. A., White, N. A., Ekstrom, J. L., Koslowsky, D. J., \& Hoogstraten, C. G. (2018). The $27 \mathrm{kDa}$ Trypanosoma brucei pentatricopeptide repeat protein is a g-tract specific RNA binding protein. Scientific Reports, $8(1)$, 16989.

Katz, A., \& Orellana, O. (2012). Protein synthesis and the stress response. In: Biyani, M. (Ed.). Cell-free protein synthesis. Издательство, город. Рp. 111-134.

Koopman, J., Aleksanyan, T., Aleksanyan, A., Fayvush, G., Oganesian, M., Vitek, E., \& Więclaw, H. (2021a). The genus Carex (Cyperaceae) in Armenia. Phytotaxa, 494, 1-41.
Koopman, J., Więcław, H., \& Waltje, H. (2021b). Carex ×terschellingensis hybr. nov. $[=$ Carex acuta $\times$ C. trinervis $]$ and Carex $\times$ reichgeltii hybr. nov. [= Carex acuta $\times$ C. aquatilis], Cyperaceae, found in the Netherlands. Gorteria-Dutch Botanical Archives, 43, 27-34.

Kosmala, A., Bocian, A., Rapacz, M., Jurczyk, B., \& Zwierzykowski, Z. (2009). Identification of leaf proteins differentially accumulated during cold acclimation between Festuca pratensis plants with distinct levels of frost tolerance. Journal Experimental Botani, 60, 3595-3609.

Kosová, K., Vítámvás, P., Urban, M. O., Prášil, I. T., \& Renaut, J. (2018). Plan abiotic stress proteomics: The major factors determining alterations in cellular proteome. Frontiers in Plant Science, 9, 122.

Kozeko, L. Y., Artemenko, O. A., Zaslavsky, V. A., Didukh, A. Y., Rahmetov, D. B., Martynyuk, G. M., Didukh, Y. P., \& Kordyum, Y. L. (2011). Evaluation of plant state under unfavorable change of environmental conditions using heat shock protein $70 \mathrm{kDa}$ (HSP 70). Ukrainian Botanical Journal, 68(6), 890-900 (in Ukrainian).

Laemmli, U. K. (1970). Cleavage of structural proteins during the assembly of the head of bacteriophage T4. Nature, 227(5259), 680-684.

Laghlimi, R. M., Baghdad, B., Hadi, H., \& Bouabdli, A. (2015). Phytoremediation mechanisms of heavy metal contaminated soils. Journal of Ecology, 5, 375-388.

Lario, L. D., Parra, E. R., \& Gutierrez, C. (2013). Anti-silencing function proteins are involved in ultraviolet-induced DNA damage repair and are cell cycle regulated by E2F transcription factors in Arabidopsis. Plant Physiology, 162(2), 1164 1177.

Levine, A. J., \& Oren, M. (2009). The first 30 years of p53: Growing ever more complex. Nature Reviews Cancer, 9(10), 749-758.

Li, N., Dejuan, E., Joon, Y. C., Zeng, L., Mengzhu, L., Li-Jun, H., \& Yeon, K. W. (2021). Plant hormone-mediated regulation of heat tolerance in response to global climate change. Frontiers in Plant Science, 11, 627969.

Liu, H., \& Charng, Y. (2012). Acquired thermotolerance independent of heat shock factor A1 (HsfA1), the master regulator of the heat stress response. Plant Signaling and Behavior, 7(5), 547-550.

Liu, H., Shi, J., Sun, C., Gong, H., Fan, X., Qiu, F., Huang, X., Feng, Q., Zheng, X., Yuan, N., Li, C., Zhang, Z., Deng, Y., Wang, J., Pan, G., Han, B., Lai, J., \& Wu, Y. (2016). Gene duplication confers enhanced expression of 27-kDa $\gamma$-zein for endosperm modification in quality protein maize. Proc Natl Acad Sci USA, 113(18), $4964-4969$.

Ma, H., Song, T., Wang, T., \& Wang, S. (2016). Influence of human p53 on plant development. PLoS One, 11(9), 0162840

Malik, N. A., Kumar, J., Wani, M. S., Tantray, Y. R., \& Ahmad, T. (2021). Role of Mushrooms in the bioremediation of soil. Microbiota and Biofertilizers, 2, 77-102.

Mishra, D., Shekhar, S., Singh, D., Chakraborty, S., \& Chakraborty, N. (2018). Heat shock proteins and abiotic stress tolerance in plants. In: Asea, A., \& Kaur, P. (Eds.). Regulation of heat shock protein responses. Springer. Pp. 41-69.

Murzin, I. R., Kositsyna, A. A., Rozentsvet, O. A., \& Makurina, O. N. (2011). Vliyanie ksenobiotikov na soderzhanie membrannosvyazannyih belkov v tkanyah vodnogo pogruzh Egeria densa [Xenobiotic effect on content of membrane proteins in tissue of water submerged plant Egeria densa]. Izvestiya Samarskogo Nauchnogo Tsentra RAN, 13(1), 257-259 (in Russian).

Nedjimi, B. (2021). Phytoremediation: A sustainable environmental technology for heavy metals decontamination. SN Applied Sciences, 3, 286.

Osakabe, Y., Yamaguchi-Shinozaki, K., Shinozaki, K., \& Tran, L. S. (2014). ABA control of plant macroelement membrane transport systems in response to water deficit and high salinity. New Phytologist, 202, 35-49.

Pakharkova, N. V., Prudnikova, S. V., Gekk, A. S., Larkova, A. N., \& Korosteleva, N. S. (2015). Optimizatsija vybora rastenij dlia bioremediatsiji pochv, zagryaznennykh neftiju i nefteproduktami v uslovijah Yuzhnoy Sibiri [Optimization of plant choice for bioremediation of soils contaminated with oil and oil products in the South Siberia conditions]. Vestnik KrasGAU, Biological Sciences, 8, 28 33 (in Russian)

Peco, J. D., Higueras, P., Campos, J. A., Esbrí, J. M., Moreno, M. M., BattagliaBrunet, F., \& Sandalio, L. M. (2021). Abandoned mine lands reclamation by plant remediation technologies. Sustainability, 13, 6555.

Pereira-Silva, L., Trevisan, R., Rodrigues, A. C., \& Larridon, I. (2020). Combining the small South American genus Androtrichum into Cyperus (Cyperaceae). Plant Ecology and Evolution, 153(3), 446-454

Qu, A. L., Ding, Y. F., Jiang, Q., \& Zhu, C. (2013). Molecular mechanisms of the plant heat stress response. Biochem Biophys Res Commun, 432, 203-207.

Romaniuk, O. I., Shevchyk, L. Z., \& Zhak, T. V. (2018). The change of oil quantity and dynamics of soil phytotoxicity at the oil pollution. Scientific and Technical Journal, 18, 7-14 (in Ukrainian).

Roose, J. L., Frankel, L. K., Mummadisetti, M. P., \& Bricker, T. M. (2016). The extrinsic proteins of photosystem II: Update. Planta, 243, 889-908.

Sasi, S., Venkatesh, J., Daneshi, R. F., \& Gururani, M. A. (2018). Photosystem II extrinsic proteins and their putative role in abiotic stress tolerance in higher plants. Plants, 7,100 
Shevchyk, L. Z., \& Romanyuk, O. I. (2017). Analiz biolohichnykh sposobiv vidnovlennia naftozabrudnenykh gruntiv [Analysis of biological methods of recovery of oilcontaminated soils]. ScienceRise: Biological Science, 1(4), 31-39 (in Ukrainian).

Sliwiak, J., Sikorski, M., \& Jaskolski, M. (2018). PR-10 proteins as potential mediators of melatonin-cytokinin cross talk in plants: Crystallographic studies of LIPR-10.2B isoform from yellow lupine. FEBS Journal, 285(10), 1907-1922.

Smith, P., House, J. I., \& Mercedes, B. (2016). Global change pressures on soils from land use and management. Global Change Biol., 22(3), 1008-1028.

Stoychev, V., Simova-Stoilova, L., Vaseva, I., Kostadinova, A., Nenkova, R., Feller, U., \& Demirevska, K. (2013). Protein changes and proteolytic degradation in red and white clover plants subjected to waterlogging. Acta Physiologiae Plantarum, 35(6), 1925-1932.

Taguchi, S., Shen, L., Han, G., Umena, Y., Shen, J.-R., Noguchi, T., \& Mino, H. (2020). Formation of the high-spin S2 state related to the extrinsic proteins in the oxygen evolving complex of photosystem II. Journal of Physical Chemistry Letters, 11(20), 8908-8913.

Takahashi, F., Kuromori, T., Urano, K., Yamaguchi-Shinozaki, K., \& Shinozaki, K (2020). Drought stress responses and resistance in plants: From cellular responses to long-distance intercellular communication. Frontiers in Plant Science, $11,556972$.

Tang, K. H. D. (2019). Phytoremediation of soil contaminated with petroleum hydrocarbons: A review of recent literature. Global Journal of Civil and Environmental Engineering, 1, 33- 42 .

Tian, F., Hu, X.-L., Yao, T., Yang, X., Chen, J.-G., Lu, M.-Z., \& Zhang, J. (2021) Recent advances in the roles of HSFs and HSPs in heat stress response in woody plants. Frontiers in Plant Science, 12, 4905.
Tsvilinjuk, O., Bunio, L., Karpyn, O., \& Pentsak, A. (2017). Fitoremediatsija naftozabrudnenykh hruntiv za dopomohoju roslyn Carex hirta L. [Phytoremediation of oil contaminated soils using plants Carex hirta L.]. Construction, Material Science, Mechanical Engineering, 99, 187-193 (in Ukrainian).

Ul Haq, S., Khan, A., Ali, M., Khattak, A. M., Gai, W.-X., Zhang, H.-X., Wei, A.M., \& Gong, Z.-H. (2019). Heat shock proteins: Dynamic biomolecules to counter plant biotic and abiotic stresses. International Journal of Molecular Sciences, 20(21), 5321 .

Villaverde, T., Jiménez-Mejías, P., Luceño, M., Waterway, M. J., Kim, S., Lee, B. Rincón-Barrado, M., Hahn, M., Maguilla, E., \& Roalson, E. H. (2020). A new classification of Carex (Cyperaceae) subgenera supported by a HybSeq backbone phylogenetic tree. Botanical Journal of the Linnean Society, 194, 141-163.

Waters, E. R., \& Vierling, E. (2020). Plant small heat shock proteins - evolutionary and functional diversity. New Phytologist, 227, 24-37.

Wawrzyńska, A., \& Agnieszka, S. (2020). Proteasomal degradation of proteins is important for the proper transcriptional response to sulfur deficiency conditions in plants. Plant and Cell Physiology, 61(9), 1548-1564.

Zahermand, S., Vafaeian, M., \& Bazyar, M. H. (2020). Analysis of the physical and chemical properties of soil contaminated with oil (petroleum) hydrocarbons. Earth Sciences Research Journal, 24(2), 163-168.

Zhang, L., Wang, Y., Zhang, Q., Jiang, Y., Zhang, H., \& Li, R. (2020). Overexpression of HbMBFla, encoding multiprotein bridging factor 1 from the halophyte Hordeum brevisubulatum, confers salinity tolerance and ABA insensitivity to transgenic Arabidopsis thaliana. Plant Molecular Biology, 102, 1-17.

Zhao, J., Lu, Z., Wang, L., \& Jin, B. (2021). Plant responses to heat stress: Physiology, transcription, noncoding RNAs, and epigenetics. Journal of Molecular Sciences, 22, 117 . 